\title{
Micromorphological Study of Site Formation Processes at El Sidrón Cave (Asturias, Northern Spain): Encrustations over Neanderthal Bones
}

\author{
Juan Carlos Cañaveras ${ }^{1}$, Sergio Sánchez-Moral ${ }^{2} \mathbb{D}$, Elsa Duarte ${ }^{3}$, Gabriel Santos-Delgado ${ }^{4}$, Pablo G. Silva ${ }^{5}$, \\ Soledad Cuezva ${ }^{6}$, Ángel Fernández-Cortés ${ }^{7} \mathbb{D}$, Javier Lario ${ }^{8}$, María Concepción Muñoz-Cervera ${ }^{1}$ and \\ Marco de la Rasilla ${ }^{3, *}$
}

1 Department of Environmental and Earth Sciences, University of Alicante, Campus San Vicente del Raspeig, E-03690 Alicante, Spain; jc.canaveras@ua.es (J.C.C.); mc.munoz@ua.es (M.C.M.-C.)

2 Department of Geology, MNCN-CSIC, C/ José Gutiérrez Abascal, 2, E-28006 Madrid, Spain; ssmilk@mncn.csic.es

3 Department of History, University of Oviedo, C/Amparo Pedregal, s/n, E-33011 Oviedo, Spain; elduarma@gmail.com

4 Department of Cartography and Terrain Engineering, University of Salamanca, Plaza de la Merced, s/n, E-37008 Salamanca, Spain; gsd@usal.es

check for updates

Citation: Cañaveras, J.C.;

Sánchez-Moral, S.; Duarte, E.;

Santos-Delgado, G.; Silva, P.G.;

Cuezva, S.; Fernández-Cortés, Á.;

Lario, J.; Muñoz-Cervera, M.C.;

Rasilla, M.d.l. Micromorphological

Study of Site Formation Processes at

El Sidrón Cave (Asturias, Northern

Spain): Encrustations over

Neanderthal Bones. Geosciences 2021,

11, 413. https://doi.org/10.3390/

geosciences 11100413

Academic Editors: Jesús F.

Jordá Pardo and Jesus Martinez-Frias

Received: 29 July 2021

Accepted: 22 September 2021

Published: 3 October 2021

Publisher's Note: MDPI stays neutral with regard to jurisdictional claims in published maps and institutional affiliations.

Copyright: (c) 2021 by the authors. Licensee MDPI, Basel, Switzerland. This article is an open access article distributed under the terms and conditions of the Creative Commons Attribution (CC BY) license (https:/ / creativecommons.org/licenses/by/ $4.0 /)$.
5 Department of Geology, University of Salamanca, Plaza de la Merced, s/n, E-37008 Salamanca, Spain; pgsilva@usal.es

6 Department of Geology, Geography and Environment, University of Alcalá de Henares, Campus Científico y Tecnológico, E-28802 Alcalá de Henares, Spain; soledad.cuezva@uah.es

7 Department of Biology and Geology, University of Almería, Ctra. Sacramento, s/n, E-04120 Almería, Spain; acortes@ual.es

8 Faculty of Science, Universidad Nacional de Educación a Distancia (UNED), Avda. Esparta, s/n, E-28232 Las Rozas, Spain; javier.lario@ccia.uned.es

* Correspondence: mrasilla@uniovi.es

Abstract: El Sidrón Cave is an archaeological and anthropological reference site of the Neanderthal world. It shows singular activity related to cannibalisation, and all existing processes are relevant to explain the specific behaviour of the concerned individuals. This paper presents geoarchaeological data, primarily based on mineralogical and petrographic techniques, from an investigation of the nature of the encrustations or hard coatings that affect a large part of the Neanderthal bone remains and their relationship with the depositional and post-depositional processes at the archaeological site. Crusts and patina were found to be numerous and diverse, mainly composed of calcite and siliciclastic grains, with different proportions and textures. The analysis indicated different origins and scenarios from their initial post-mortem accumulation to the final deposit recovered during the archaeological work. The presence of micromorphological features, such as clotted-peloidal micrite, needle-fibre calcite (NFC) aggregates, clay coatings, iron-manganese impregnation, and/or adhered aeolian dust may indicate that a significant proportion of the remains were affected by subaerial conditions in a relatively short period of time in a shelter, cave entrance, or shallower level of the karstic system, prior to their accumulation in the Ossuary Gallery.

Keywords: cave sediment; karst; geoarchaeology; palaeoanthropology; Middle Palaeolithic; Mousterian; Iberian Peninsula

\section{Introduction}

The Neanderthal fossils from the archaeological site of El Sidrón cave comprise, for the moment, the largest and most complete anthropological collection of these species found on the Iberian Peninsula. They consist of $~ 2530$ skeletal remains belonging to 13 individuals with familial relationships and evidence of cannibalism [1-9]. However, Mousterian lithic artifacts are quite scarce $(\sim 400)$, and they are made from local chert and quartzite, indicating 
short and expedient behaviour. The high refitting rate of lithics (20\%) unequivocally proves a single archaeological deposit $[10,11]$. Animal bones are very scarce, and they are not related to human activities [12].

A multi-dating approach has been undertaken at the site, and it has given a consistent date of 48,400 \pm 3200 years BP for the archaeological and the fossil assemblage, which places it between Heinrich's H4 and H5 events of the paleoclimatic stage MIS 3 [12-14]. It is precisely this period in which a good percentage of the so-called "classic Neanderthals" are concentrated, among which we can place the El Sidrón Neanderthal group.

The specificities of this collection (more human bones than lithic and unconsumed fauna) are opposed to a Neanderthal permanent site, as determined by the deposition pattern in the small Ossuary Gallery [1,6,10]. Although the preservation of the bones is generally fairly good, with very limited trampling or erosion and no carnivore or rodent toothmarks, bones and lithics are not in their original location. Geo-archaeo-stratigraphic analyses have suggested that the bones went into the cave in a massive water-driven deposit and fell into the Ossuary Gallery through a vertical shaft, probably resulting from a flood event after a thunderstorm [15-19].

This rapid event into the cave allowed for the good preservation of both sediments and archaeological remains. This preservation is a common feature related to caves and rock shelters because they are little-exposed to open-air alterations, so data regarding human past activities and the local environment can be obtained [20-24]. To a large extent, the general good preservation of fossil remains is due to their rapid incorporation into an endokarstic context, where micro environmental stability conditions favour the preservation of bone fragments [21-24]. Alteration processes begin immediately after the sedimentary input is accumulated in an archaeological deposit, and several environmental factors, such as groundwater and sediment composition, $\mathrm{pH}$, redox potential, temperature, and biological activity, can determine the preservation of archaeological bones [25-30]. Once the sediments and the archaeological remains are deposited, the taphonomic processes, related to cultural and environmental factors, are diverse in each site [24].

At El Sidrón cave, cultural and animal factors are absent because an important part of the karst conduits of the cave, and more specifically the Ossuary Gallery, were isolated from the human and animal activity after the accumulation of the massive water-driven deposit. The subsequent natural factors have consisted of low-energy processes typical of a vadose environment, evinced by, among others, encrustation. A significant number of the human fossil remains are coated in authigenic mineral concretions, with abundant fine detrital material adhered. Different types of isolated or laminar mineral (such as carbonate and Fe-Mn oxides) concretions can be distinguished. Establishing the depositional and post-depositional history of such crusts is necessary in order to evaluate a detailed contextualization of the fossils and to improve our understanding of the formation processes of the site. This paper presents geoarchaeological data related to hard coatings (crusts) and patina covering Neanderthal bones from a mineralogical and petrographic study in order to further investigate the circumstances of the original deposition, the post-depositional processes, and the preservation of the archaeological site.

\section{Geological Setting and Sediment Sequence}

El Sidrón cave was developed in Oligocene carbonate conglomerates alternating with fine to medium-grained sandstones. These carbonate successions show approximate $\mathrm{E}-\mathrm{W}$ directions, dipping $20-30^{\circ}$ to the north. The karst system, with a development of $600 \mathrm{~m}$ (about $3700 \mathrm{~m}$ in galleries) and a height difference of 30-32 $\mathrm{m}$ between the highest galleries and the spring, is divided into four levels with a main $\mathrm{E}-\mathrm{W}$ direction; these were generated according to the evolution of the regional drainage system. The Main Gallery (Gallery of the River) and its transverse tributaries (i.e., Ossuary Gallery) are located in the second level, just above the active (phreatic) level. The Neanderthal bone assemblage is located in the Ossuary Gallery, an N-S oriented passage that is $\sim 28 \mathrm{~m}$ long and $12 \mathrm{~m}$ wide (Figure 1). 


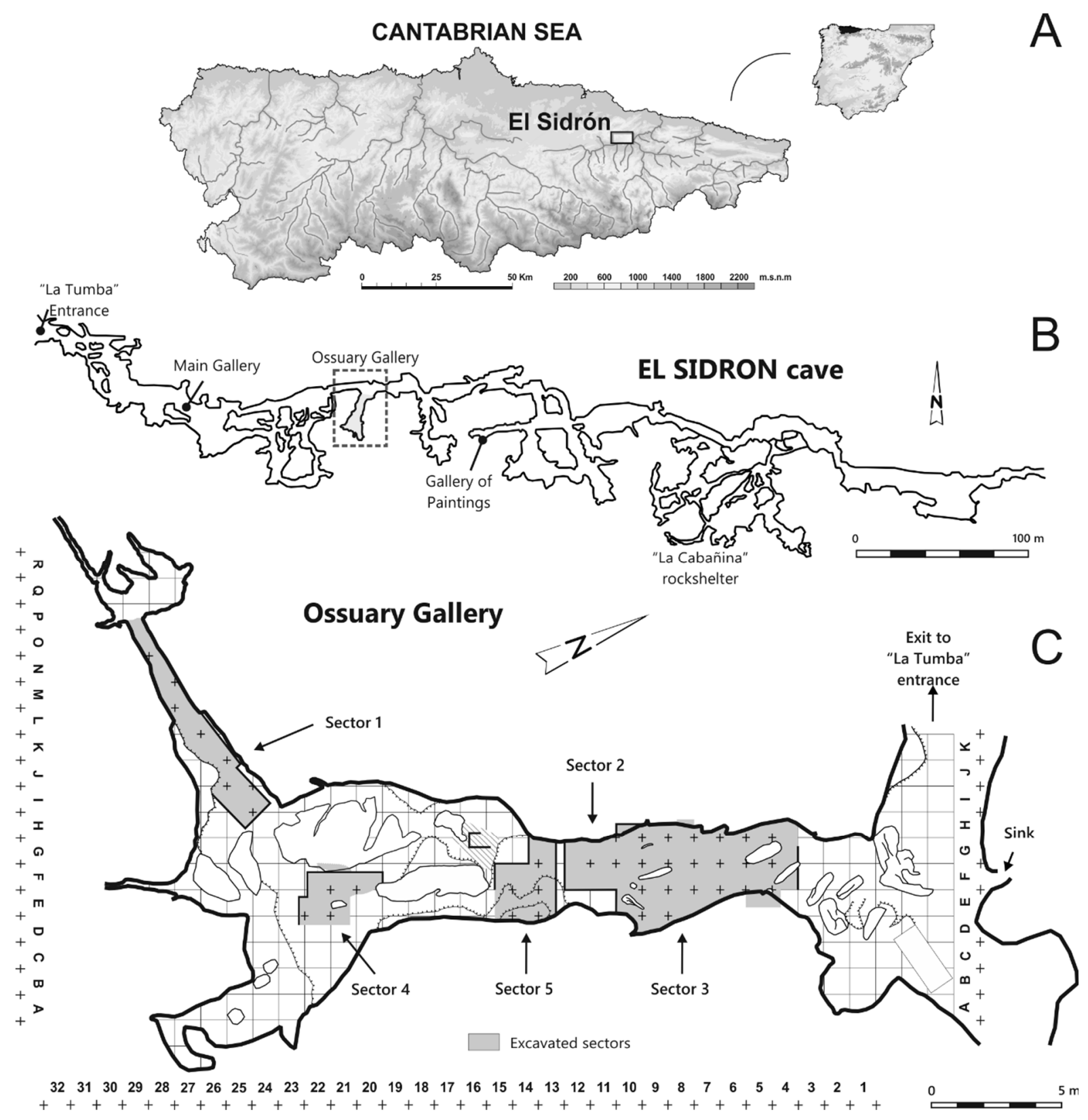

Figure 1. El Sidrón cave: (A) Geographical location of the El Sidrón cave; (B) cave map with the location of the main galleries; (C) excavation plan of the Ossuary Gallery.

The sedimentary infill in the Ossuary Gallery shows great complexity, thus making it hard to define a stratigraphic column representing the whole gallery. Five main units corresponding to events with different hydrodynamic and sedimentary characteristics are better documented in the central zone of the Ossuary Gallery [16,19,31] (Figure 2). From bottom to top, these are:

- Unit 0 , a unit of massive mud. No clear sedimentary structures can be distinguished. In a preliminary approach, they seem to be sediments deposited through a low energy outflow or backswamp conditions.

- Unit I, a unit of laminated fine sands and mud, with cross-stratification. It includes low-intensity fluvial-karstic material with a relative increase in energy at the top.

- Unit II, a unit of poorly sorted gravels, sands, and mud. It represents the lower limit of the 'fossiliferous units' (units where Neanderthal bones are embedded) so far. The fluvial-karstic materials originated from a high energy event and are clearly erosive 
to underlying sediments, especially in the eastern and central parts of the gallery. This unit corresponds to a diamicton facies.

- Unit III, a unit of massive clays with dispersed levels of gravels, sands, and silts. Interbedded silts and fine sands showing fluid escape structures are common. At the base, this unit is very similar to Unit II and the grain size diminishes towards the top in general terms. In the western part of the gallery, the grain size of the unit is also coarser, with a predominance of pebble and gravel deposits. At the top of the unit, a prominent feature is the existence of calcareous crusts (IIIc) of variable thickness and texture, with a horizontal arrangement and a high lateral continuity. These speleothemic crusts (flowstone) reach a greater development and thickness towards the east wall of the gallery (Figure 3).

- Unit IV, a unit of massive mud with some interbedded sands. These sediments formed in a very low energy fluvial-karstic environment and correspond to the final infill episode in the gallery, which can be regarded as still in progress.

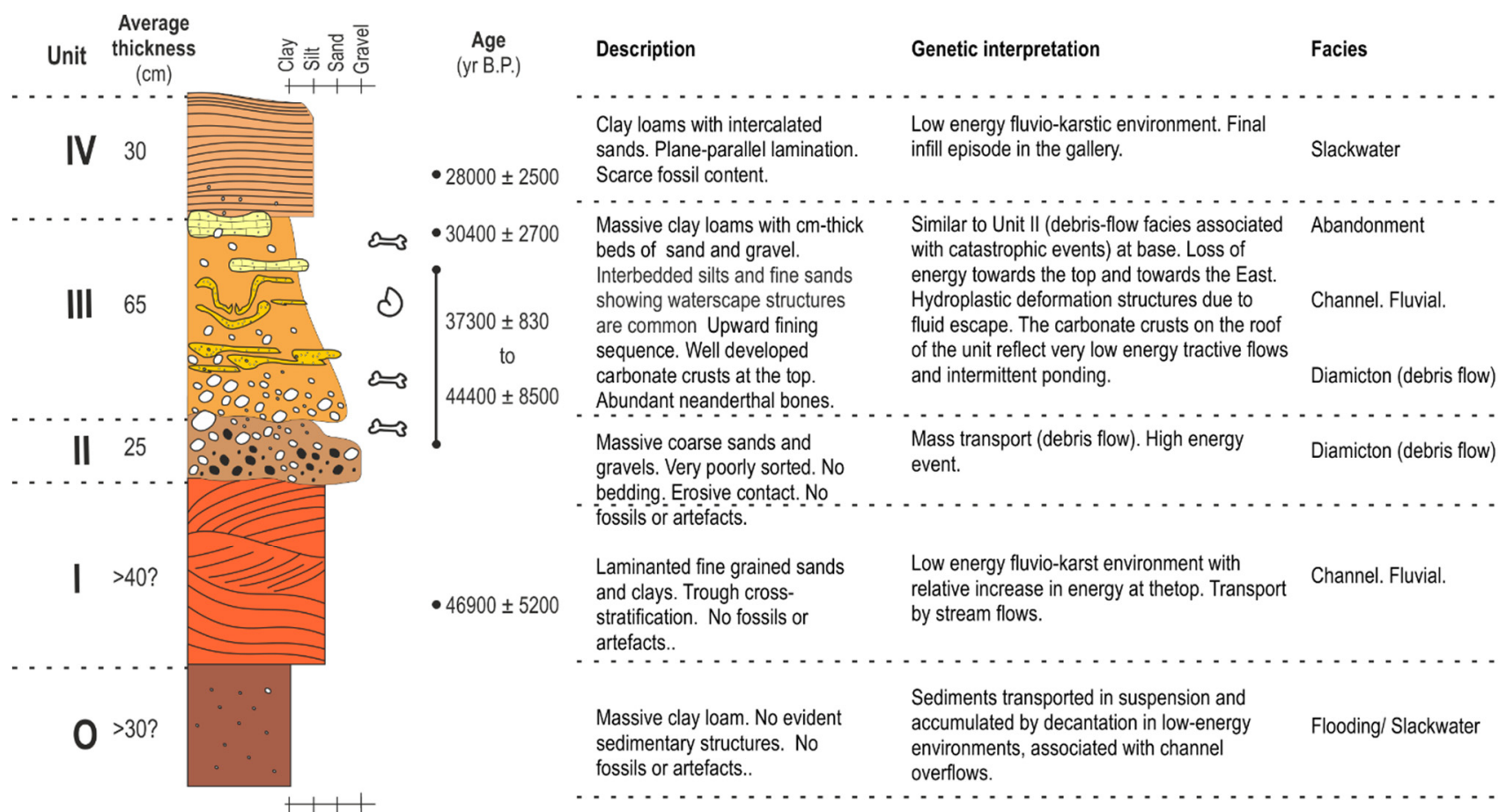

Figure 2. Stratigraphic column from the central zone of the Ossuary Gallery (Sector 3), with a brief description of the main sedimentary units and their genetic interpretation. Modified from Cañaveras et al. [16,18].

The vast majority of the anthropological and archaeological material is concentrated between squares E-H/10-E-H/4 in Unit III, which corresponds to Sector 3 (Figure 3). Considering the whole sediment, this unit is made up of poorly sorted gravelly muddy sands. The mineralogy of the fine fraction is markedly siliceous, with quartz (70-85\%) and clays (5-25\%) as dominant mineral phases [3,4,16]. Feldspars and calcite (mainly bioclast and rock fragments) usually do not exceed $10 \%$ and $5 \%$, respectively. The clay fraction is mainly composed of kaolinite (25-75\%), illite (20-50\%) and smectite (5-25\%). Sand-size grains are usually angular-to-subangular in shape, with a typology concordant with host rock (Oligocene arenites from Pudinga de Posadas Fm.) [16-18]. Subrounded gravel-sized fragments of Santonian limestones (biopelmicrites and biopelsparites), also from the embedding rock (Pudinga de Posadas Fm.), are common at the base of the unit. Micromorphological characters that reflect post-depositional processes, whether edaphic or not, are very scarce in the sedimentary fill of the gallery in general and, particularly, in Unit III $[1,10]$. These are restricted to clay/silt translocation processes that can be observed 
as coatings around voids and the iron-manganese staining of some levels that delineate fluid escape structures $[3,4,10,16]$.
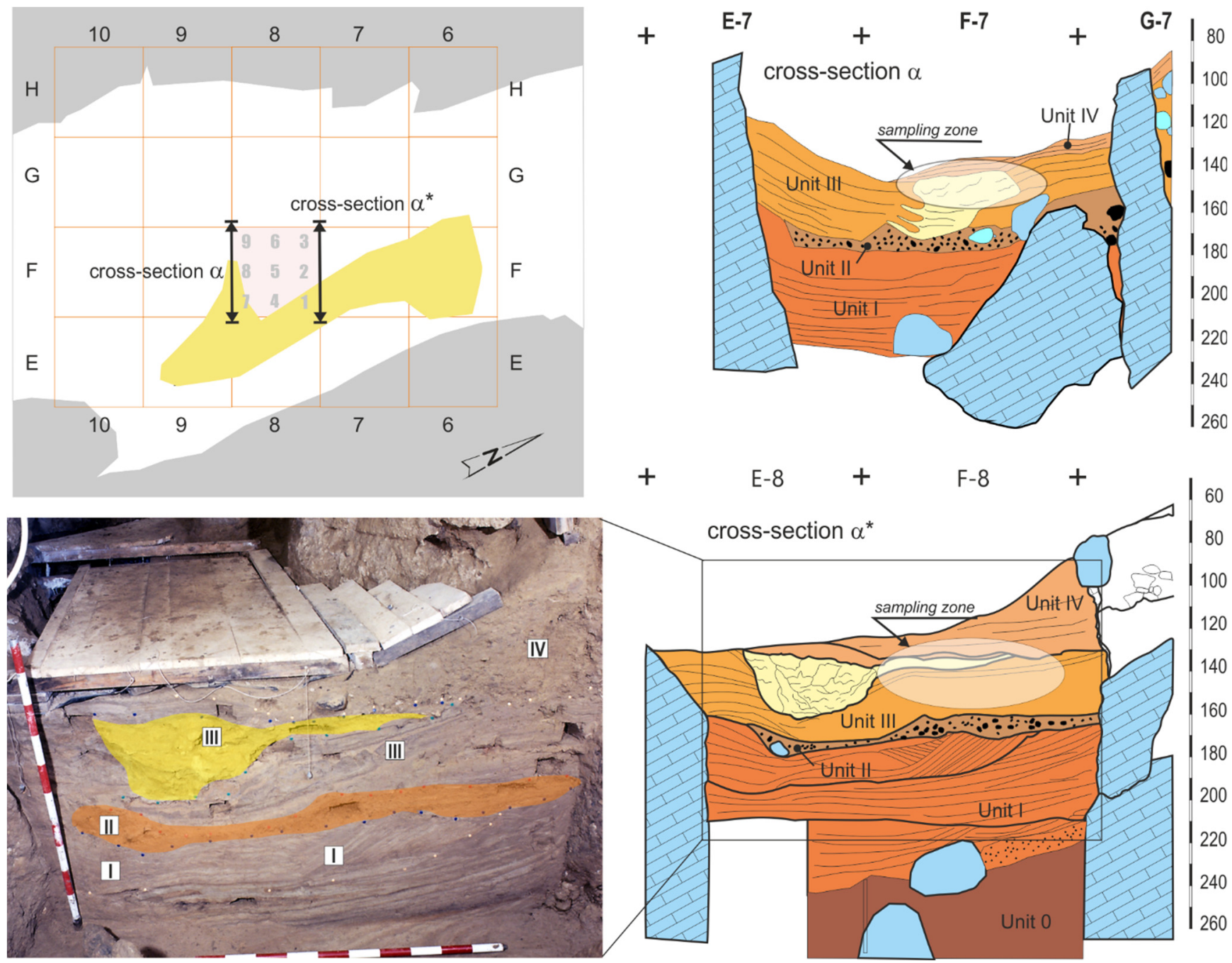

Figure 3. Excavation plan of Sector 3 with the location of the upper calcareous crust subunit in yellow (Unit III) and sampling zone detailed in the lithostratigraphic sections (square F8).

The geological analysis of the sediments suggests that all the archaeological record (the Neanderthal and the lithic remains) dropped into the cave from a higher level in the karstic system via a vertical shaft in a massive flow deposit as a result of a collapse after a high-energy event, probably a thunderstorm [16,19,31]. Several pieces of evidence suggest that the archaeological and anthropological remains were deposited near-simultaneously shortly before the high energy event: marks left by the mentioned gnawing of carnivores and rodents are absent, articulated Neanderthal bones are present, and a high refitting rate of the lithic industry has been observed (studies are ongoing) [11]. Additionally, the relatively good condition of the bones indicates that they came from the outside, but they must have been deposited in a protected environment (e.g., a surficial gallery near the entrance or a rock shelter) and, given the scant traces of alteration documented on the bones, their exposure time in surface conditions must have been very short [2,12,32].

The morphology of the Ossuary Gallery (i.e., width, length, and sinuosity) has influenced the hydrodynamic behaviour of the cavity, resulting in steep energy from south to north, which is reflected in the complex distribution of different sediment facies. The special configuration of the bottom of the gallery (sponge-work) has determined the complex geometry of its sediment infill, but, in turn, has favoured the preservation of 
archaeo-anthropological material. In this sense, many of these fossiliferous deposits have been trapped in rock nooks and then rested (well-protected) from episodes of sediment reworking and destruction, which are common in karst dynamics.

\section{Materials and Methods}

In order to document the site formation processes operating at the El Sidrón archaeological site, the sediments that fill the Ossuary Gallery, including those that constitute the host sediment of the samples under study in the present work, have been characterized both in situ and in the laboratory (granulometric and petrographic analysis, mineralogical and geochemical characterization, etc.) $[1,3,4,16,19]$.

A total of 8 samples corresponding to bone fossil remains (Figure 4) and 5 samples corresponding to black coatings and or impregnations were mineralogical and texturally studied (Sid. 01, 02, 04, 05, and 06). The samples were selected as the most representative of the El Sidrón archaeological record in order to study their depositional and post-depositional evolution; they were also selected because doing so would not negatively interfere with the anthropological and palaeogenetic studies. All of these samples came from Unit III and square F8, located in Sector 3 at the central part of Ossuary Gallery (coinciding with the upper part of Unit III), where a great number of human remains have been found $[11,19]$.
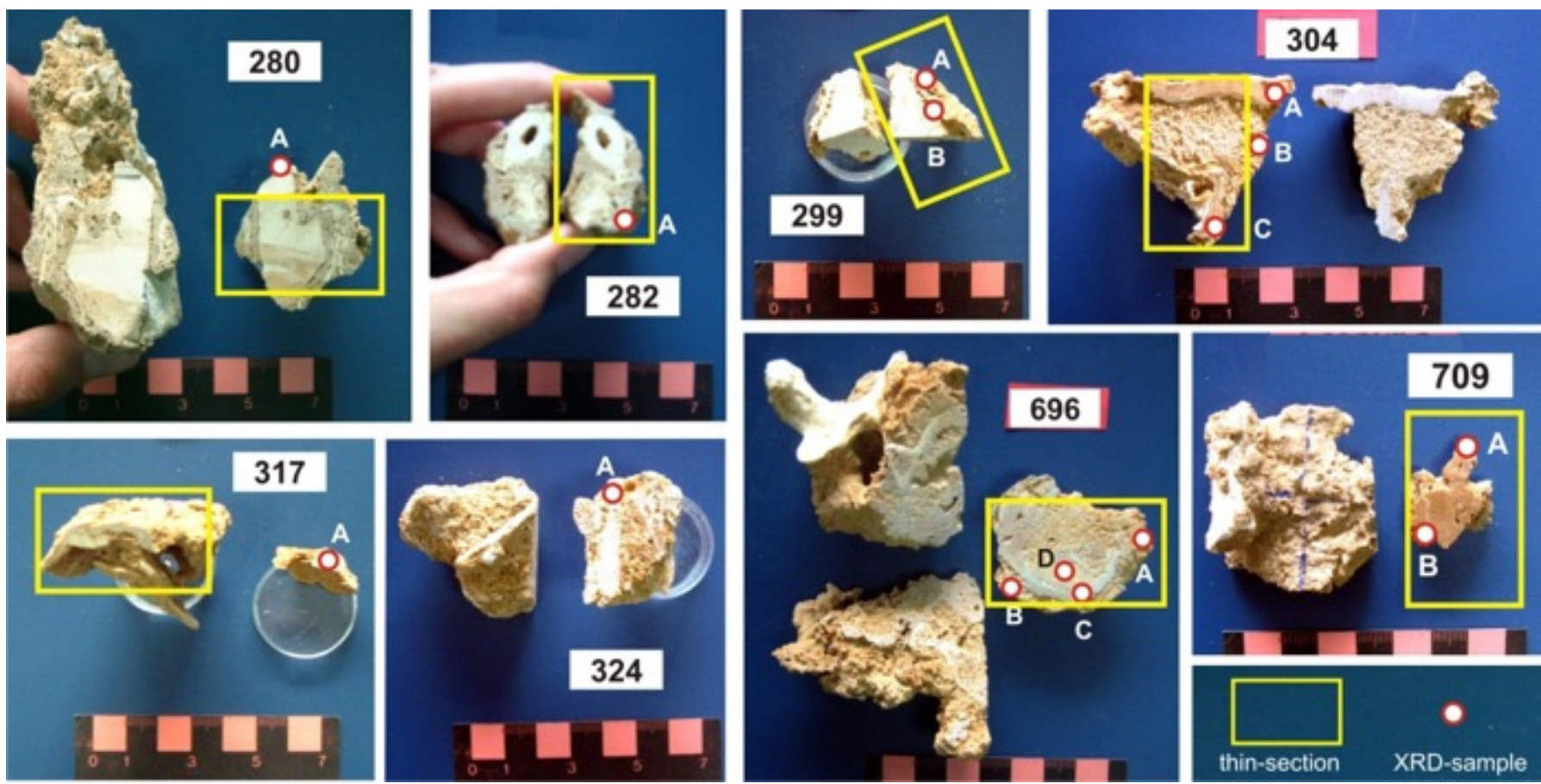

Figure 4. Bone remains with sampled calcareous concretions. The locations of both XRD analyses (dots) and thick sections (yellow rectangles) are given. See Table 2 for A, B, C, D.

The detailed locations and characteristics of bone samples are given in Table 1. The collected samples were micromorphologically and compositionally characterized using different analytical techniques. 
Table 1. Analysed samples indicating their locations in the Ossuary Gallery.

\begin{tabular}{ccccccc}
\hline Sample & Square & $\begin{array}{c}\text { Sub- } \\
\text { Square }\end{array}$ & $\mathbf{X}(\mathbf{c m})$ & $\mathbf{Y}(\mathbf{c m})$ & $\mathbf{Z ~ ( c m )}$ & $\begin{array}{c}\text { Neanderthal Bone } \\
\text { (Anatomical Part) }\end{array}$ \\
\hline 280 & F8 & 5 & 38 & 48 & 144.0 & Indeterminate \\
282 & F8 & 6 & 51 & 82 & 133.0 & Indeterminate \\
299 & F8 & 2 & 21 & 60 & 149.0 & Incisor \\
304 & F8 & 4 & 57 & 30 & 150.5 & Vertebra \\
317 & F8 & 2 & 17 & 59 & 156.0 & Scapula \\
324 & F8 & $2 / 3$ & 20 & 70 & 139.5 & Indeterminate \\
696 & F8 & 7 & 80 & 18 & 135.0 & Vertebra \\
709 & F8 & 9 & 81 & 80 & 151.0 & Rib \\
\hline
\end{tabular}

X-ray diffraction, with quartz as an internal standard, was used to determine the mineral composition of the powdered samples. The analyses were performed by using a PHILIPS PW-1710 XR-diffractometer from Museo Nacional de Ciencias Naturales (MNCNCSIC, Madrid) operating at $40 \mathrm{kV}$ and $30 \mathrm{~mA}$ under monochromatic $\mathrm{CuK} \alpha$ radiation. The diffraction patterns were obtained with a continuous scan from $3^{\circ} 2 \theta$ to $60^{\circ} 2 \theta$, with a $0.01^{\circ}$ $2 \theta$ resolution. The XPOWDER ${ }^{\circledR}$ program [33] was used to evaluate the semi-quantitative mineral compositions of the samples.

Petrographic and micromorphological conclusions were made based on the examination of standard and double-polished thin sections with conventional transmitted light microscopy (Zeiss Assioskop with a digital camera). The samples were preliminarily observed under a stereoscopic microscope at low magnification.

To complete the textural and compositional characterization of the samples, etched and unetched specimens of rock fragments and polished thin sections were studied using an FEI QUANTA 200 scanning electron microscope, with an analytical X-ray energy dispersive analysis system (EDS) of the MNCN-CSIC laboratory working at $30 \mathrm{kV}$.

\section{Results}

All the bone remains from El Sidrón cave are embedded in a dense, poorly sorted, sandy-silt matrix with a porphyritic, coarse-/ fine-related distribution (coarser fragments floating in a finer matrix). They are highly dehydrated, crumbly, and have multiple microcracks that, in some cases, have become cracks and fractures (Figure 5A,B). The degree of physical deterioration is variable, from fragments that present a marked fragmentation that makes their morphological study impossible to those that fully retain their morphology [2,34]. Additionally, a large amount of the bones appear to be coated with authigenic mineral coatings of different types and developments that are sometimes interbedded with different type of crusts.

Calcite is the most common authigenic mineral associated with bone remains at the site. Additional clay-rich and/or Fe-Mn-rich coatings and associated structures have been recognized (Table 2). Calcite is found as a micro-mesocrystalline precipitates both at bone surfaces and in the bone mass itself, as sparry calcite completely filling osteonal cavities, and along structural weakness in the bone (Figure 5C-F). 

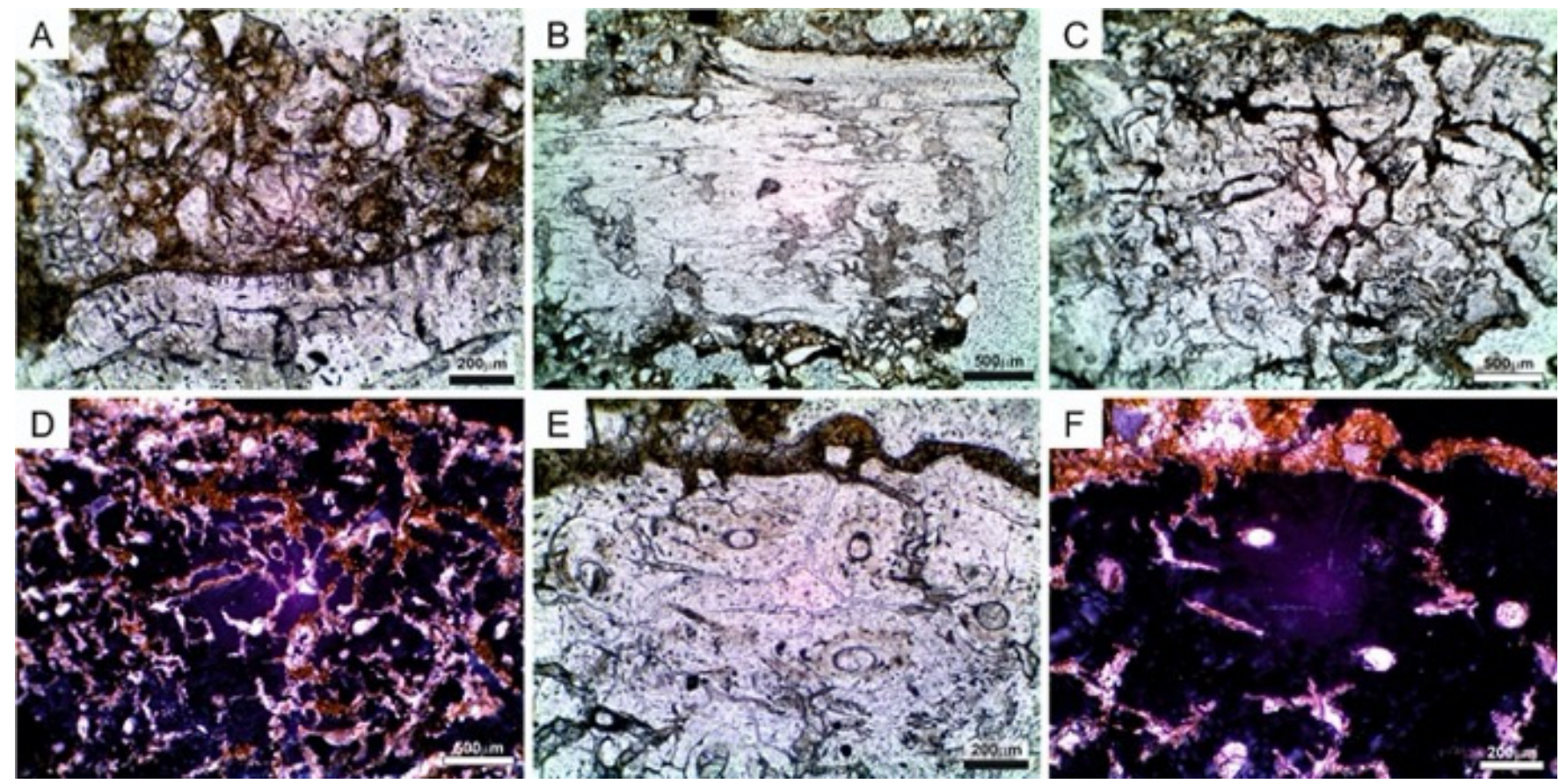

Figure 5. Microphotographs of indeterminate bone fragments: (A) microcracks affecting bone surface (Sample 280); (B) detail of splintered bone fragment (Sample 324); (C,D) calcite aggregates and Fe-Mn precipitates, respectively, filling osteonal cavities (Sample 282); (E,F) thin silty micritic crust on bone surface, with detail of calcite crystals filling osteonal channels and other micropores (Sample 282). Microphotographs (A-C,E) were taken under plane-polarized light; (D,F) were taken under crossed nicols.

Table 2. Mineral composition of the analysed samples. See Figure 4 for the location of each sample.

\begin{tabular}{cccccc}
\hline Sample & $\begin{array}{c}\text { Crust } \\
\text { Subtypes }\end{array}$ & Calcite (\%) & Quartz (\%) & $\begin{array}{c}\text { Feldspars } \\
(\mathbf{\%})\end{array}$ & $\begin{array}{c}\text { Hydroxyl-Apatite } \\
\text { (\%) }\end{array}$ \\
\hline 280-A & $\mathrm{T}$ & 53 & 39 & 8 & $<5$ \\
$282-\mathrm{A}$ & $\mathrm{T}$ & 62 & 33 & & \\
$299-\mathrm{A}$ & $\mathrm{T}$ & 64 & 36 & & \\
299-B & $\mathrm{Cm}$ & 87 & 13 & & \\
304-A & $\mathrm{Cp}$ & 68 & 32 & \\
304-B & $\mathrm{T}$ & 80 & 20 & \\
304-C & $\mathrm{T}$ & 71 & 12 & \\
317-A & $\mathrm{Cm}$ & 79 & 21 & \\
324-A & $\mathrm{T}$ & 45 & 34 & & \\
696-A & $\mathrm{Cm}$ & 96 & 4 & & \\
696-B & $\mathrm{T}$ & 63 & 37 & & \\
696-C & $\mathrm{Cp}$ & 78 & 22 & & \\
696-D & $\mathrm{T}$ & 67 & 33 & & \\
709-A & $\mathrm{T}$ & 52 & 48 & & \\
709-B & $\mathrm{T}$ & 50 & 50 & & \\
\hline
\end{tabular}

(T) Silty-sandy calcite crust; (Cp) sparitic calcite crust; (Cm) micritic calcite crust.

At bone surface, several types of calcareous crusts have been discriminated, mainly attending to the type of cementing phase and the amount and nature of the grains. Some of the studied bone fragments show several associated crust types. A schematic representation of each type, as well as the distribution and spatial relationship of each of these types in the studied samples, is shown in Figure 6. 

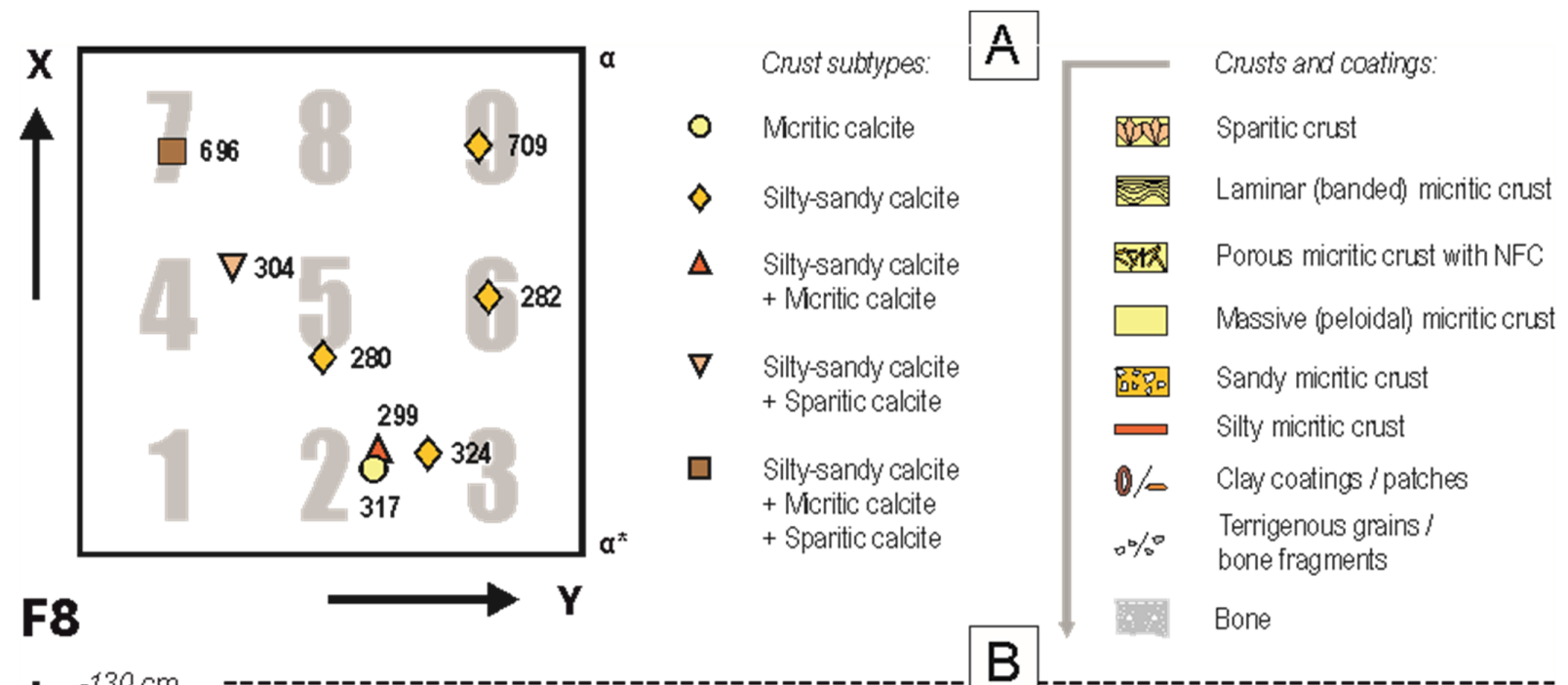

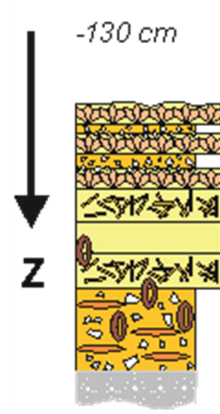

696

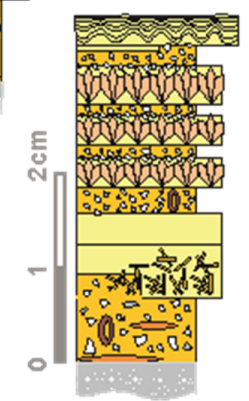

304

The

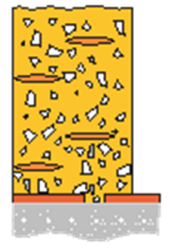

280

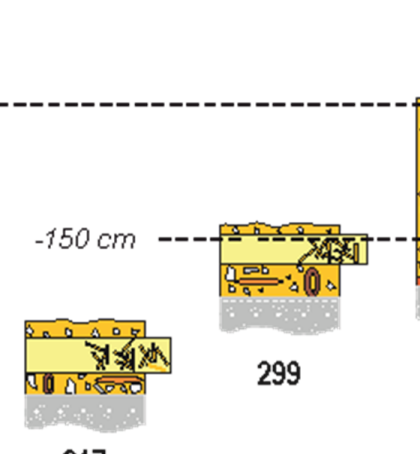

317
Depth from point 0 of excavation (Z)
$\quad$ Point 0 of Ossuary Gallery is located at 157.3 masl

ThC Thickness of the crusts (cm), standandized scale for all of them

Figure 6. Distribution of the different types of carbonate crusts (hard coatings) recognized over the Neanderthal bones (square F8): (a) horizontal distribution and crust associations; (b) vertical distribution and thickness of the crusts. See Figures 1 and 3 for locations in the Ossuary Gallery map.

\subsection{Calcite Crusts with Abundant Siliciclastic (Terrigenous) Grains}

Calcite crusts with abundant siliciclastic (terrigenous) grains are the most abundant and occur in direct contact with the bone in most samples. Their content of clay and/or Fe-Mn oxides-hydroxides is variable. Two subtypes can be distinguished:

- Silty (orange) crusts discontinuously adhere to some of the bones and locally infiltrate through cracks and fractures. They consist of micritic crusts of a yellowish-orange hue about $50-500 \mu \mathrm{m}$ thick, directly adhering to bone surface (Figure 7A). These crusts are quite dense and compact, and they are mainly composed of micritic cement, with clays (predominantly illites), some iron oxide, and a few small $(25-50 \mu \mathrm{m})$ terrigenous grains (such as quartz and feldspars).

- Sandy (yellowish) crusts up to $2-3 \mathrm{~cm}$ thick, directly developed on the surface of the bones or on the previously described silty crusts. Their colour is lighter, and their clays and iron oxide content are lower and more dispersed. On the contrary, the content of terrigenous grains is higher (Figure 7B). The nature of the grains is mostly quartz, with a very variable size $(40-800 \mu \mathrm{m})$ and the majority being $50-250 \mu \mathrm{m}$ thick. Quartz grains seem to display a bimodal sorting with fine, subangular (dominant), and coarser rounded grains. Feldspars, metamorphic rock fragments, and carbonate 
bioclasts are also present, although to a lesser extent, as are bone fragments (chips) of varying size and morphology (Figure 7C,D). The size of the calcitic cement crystals is microsparitic to mesosparitic $(40-100 \mu \mathrm{m})$, and an increase in the size of the detrital grains and in the porosity can be observed as one moves away from the bone surface. There are darker (orange) areas that are irregularly dispersed and about $50 \mu \mathrm{m}$ thick; these correspond to a higher content of clays and smaller size of the quartz grains and crystals of calcite cement. Voids are scarce and mostly correspond to regular vugs or planes. Associated with large voids, discontinuous clayey cutans (clay coatings) can be observed, as can some calcitic cement fillings consisting of palisades (sometimes radially arranged) composed of calcitic tabular crystals with a maximum length of $0.5-0.6 \mathrm{~mm}$. This type of crust is the most abundant at the studied sector of the site.
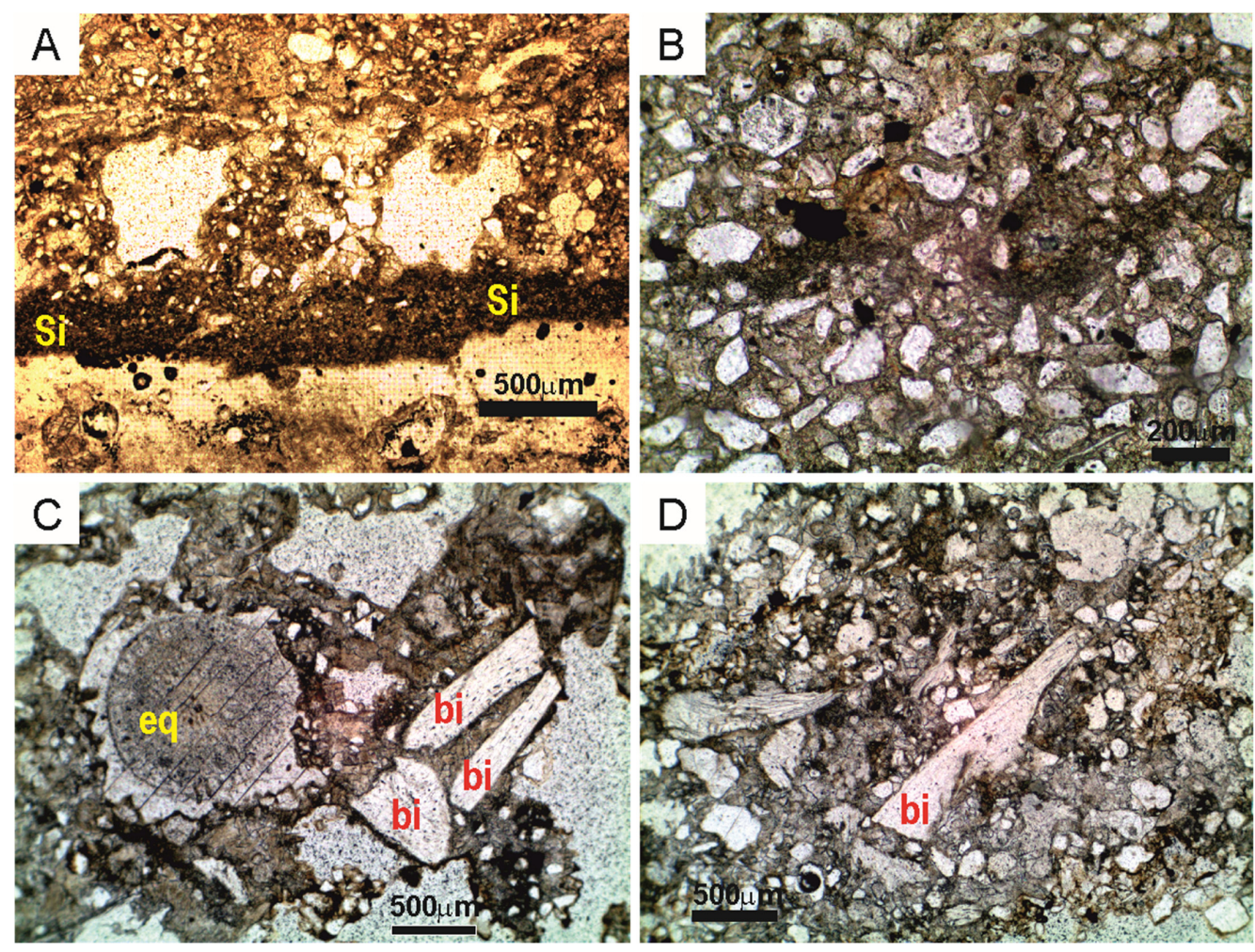

Figure 7. Microphotographs of feature characteristics of calcite crusts with abundant siliciclastic grains: (A) thin silty micritic crust (Si) on bone surface; a net contact with the overlying sandy and more porous crust can be observed (Sample 280). (B) Detail of sandy crust with a high proportion of subangular quartz grains in a micrite matrix (Sample 709). (C) Bioclast (echinoderm) (eq) and bone fragments (bi) in sandy micritic crust (Sample 324). (D) Bone fragments (bi) in sandy micritic crust (Sample 324). All microphotographs were taken under plane-polarized light.

\subsection{Calcite Crusts without (Or with Few) Siliciclastic (Terrigenous) Grains}

Two subtypes of calcite crusts without (or with few) siliciclastic (terrigenous) grains can be distinguished:

- $\quad$ Sparitic crusts alternating (sometimes erosively) with terrigenous-rich crusts. They consist of layers of palisades composed of millimetre-thick calcite crystals that alternate with bands rich in terrigenous grains (Figure 8A,B). Together, they constitute a $2-3 \mathrm{~cm}$ thick banded precipitate. There are areas of compact palisades showing banding growth and very porous areas showing the growth of large clustered or arborescent crystals that are somewhat zoned and sometimes present displacing textures (Figure 8C). Remobilized areas can also be observed with crystals or aggregates of broken and moved crystals, as well as local patinas (cutans) of clays and oxides (Figure 8D). The crystals that make up the palisades-both the compact and arbores- 
cent ones-usually show scalenohedral terminations, and morphologies similar to regrown skeletal crystals and/or calcitic rafts can be observed (Figure 9).

- Micritic crusts, normally with a compact and massive microstructure and locally characterized by the presence of an irregular lamination involving the alternation of (1) dark laminae (0.05-0.2 mm thick) of dense micrite and (2) laminae of variable thickness $(0.1-1 \mathrm{~mm})$ consisting of less dense, clotted-to-peloidal micrite-microsparite that locally present with a wavy-cloudy structure (Figure 10A,B). Areas with the presence of dispersed terrigenous grains (mainly quartz) of variable size $(25-100 \mu \mathrm{m})$ are present. Peloidal or spherical structures have diameters ranging between 5 and $80 \mu \mathrm{m}$ (Figure 10B). In some cases, acicular crystals (1-2 $\mu \mathrm{m}$ thick and approximately $10 \mu \mathrm{m}$ long) are present in a random deposition (Figure $9 \mathrm{C}$ ). These are whisker or needle-fibre calcite (NFC) morphologies (Figure 10C). They are arranged to fill small pores or partially cover the large ones in association with the clayey patina (clay coatings and cutans) (Figure 9D). In some cases, their recrystallization to microsparite crystals is intuited. In the sometimes-transitional contact zones with the yellow-orange terrigenous-rich crusts, the abundance of fibrous textures, NFC, is significantly higher. In some cases, an undulating banded arrangement can be observed (Figure 9A).
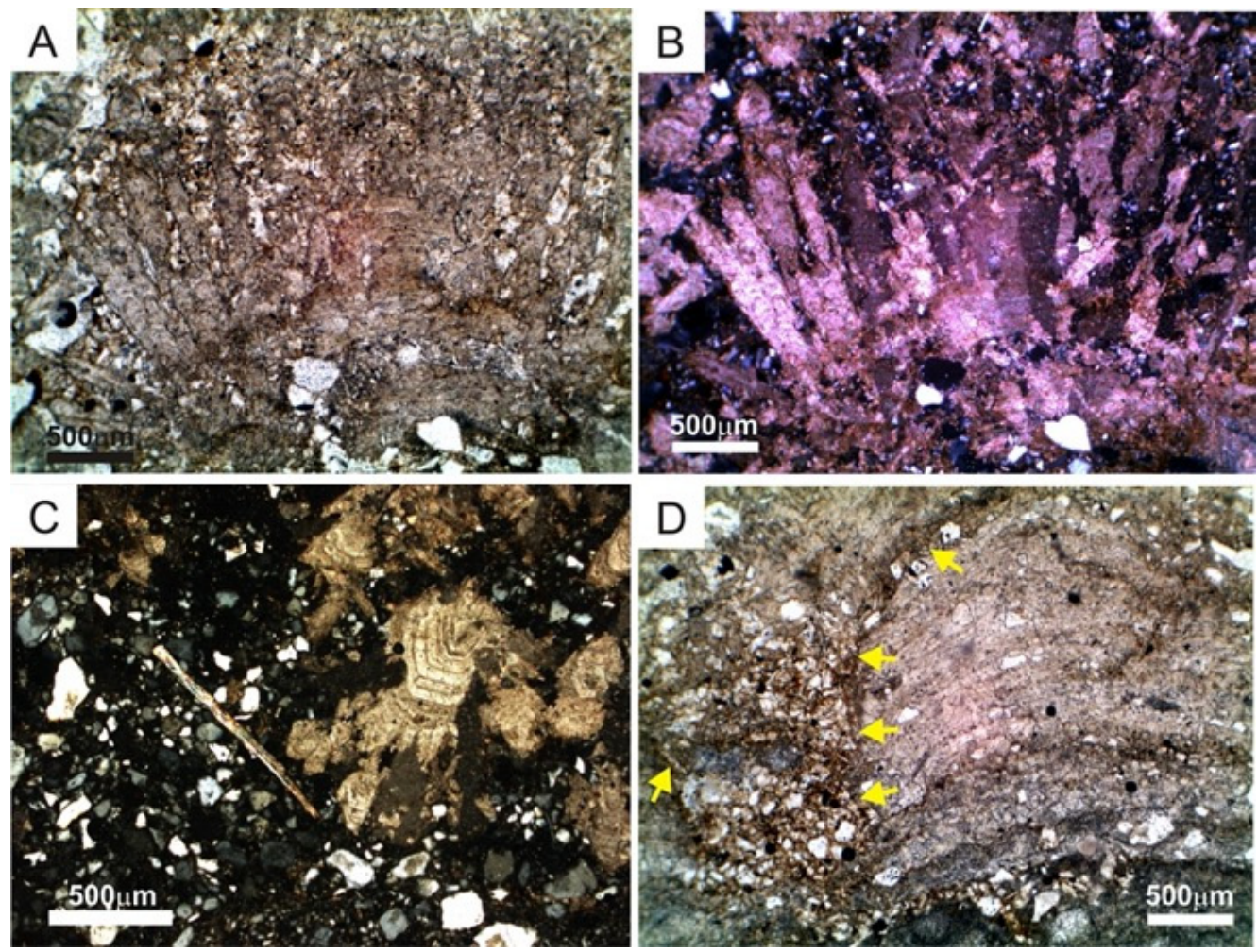

Figure 8. Microphotographs of feature characteristics of sparitic crusts: (A,B) columnar fabric composed of elongate calcite crystals with irregular boundaries, some of them dissolved and filled by detrital grains (Sample 304); (C) detail of arborescent-zoned calcite crystals (Sample 304); (D) detail of erosive contact (arrows) between sparitic laminar layers and overlaying sandy micritic crust (Sample 696). Microphotographs (A,C,D) were taken under plane-polarized light; (B) was taken under crossed nicols. 

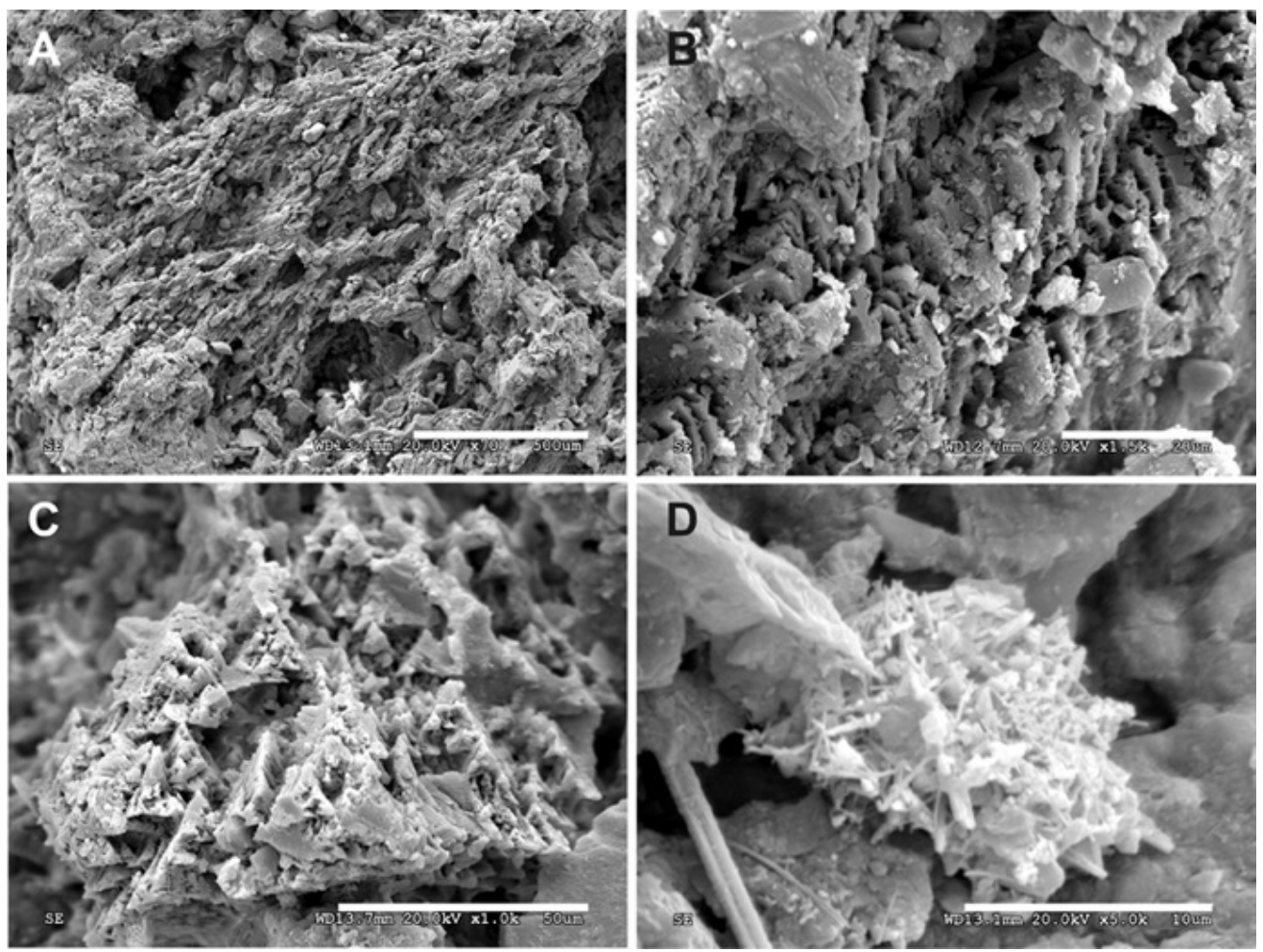

Figure 9. SEM micrographs of sparitic calcite crust: (A,B) partially dissolved scalenohedral calcite crystals (Sample 304); (C) detail of calcite scalenohedral terminations (Sample 696); (D) microcrystalline aggregate with needle-fibre calcite (NFC) crystals (Sample 696).
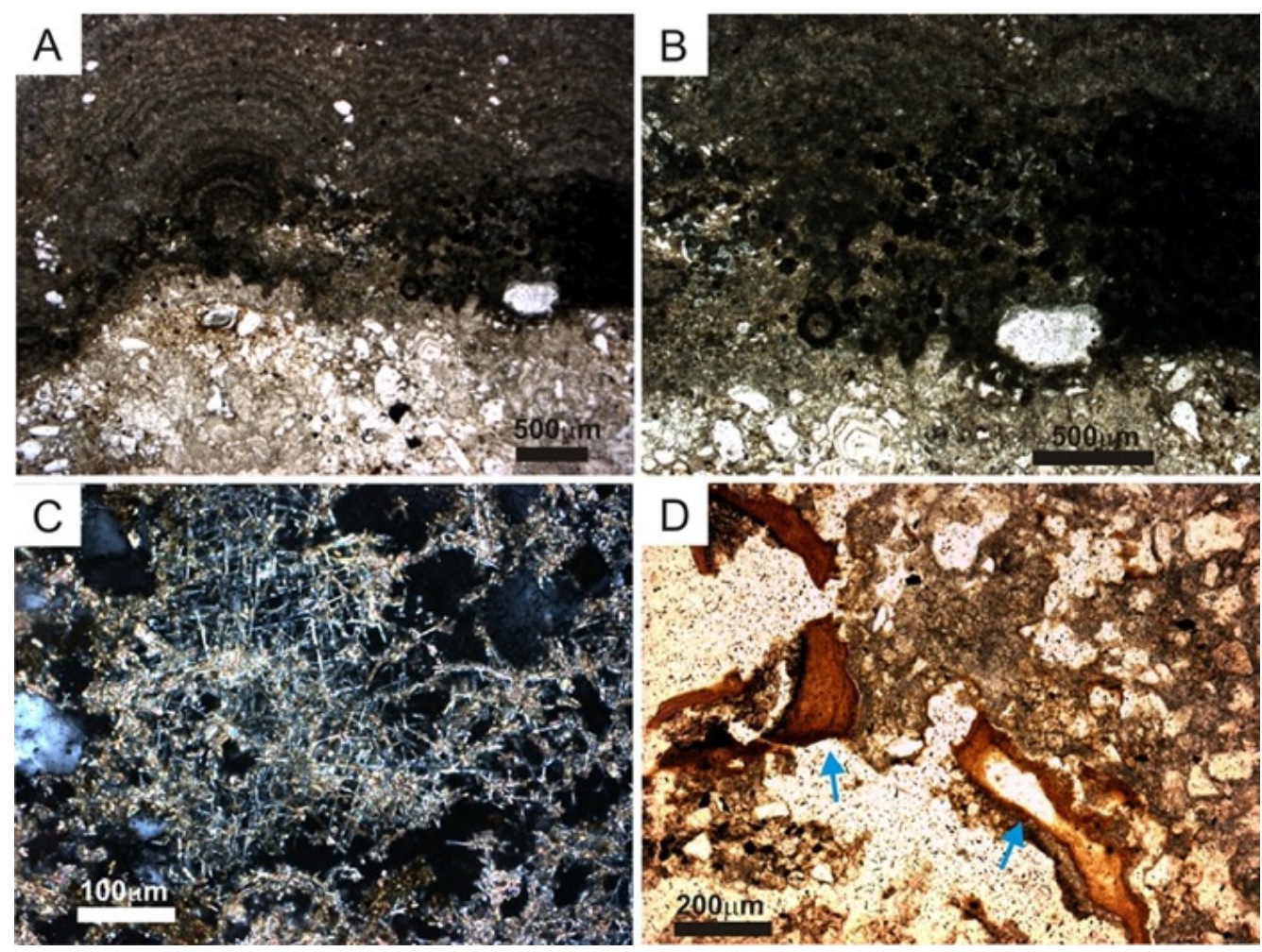

Figure 10. Microphotographs of feature characteristics of micritic crusts: $(\mathbf{A}, \mathbf{B})$ compact micritic crust composed of the alternation of dense and clotted laminae, with details of peloidal structures (Sample 304); (C) NFC crystals in a random aggregate (Sample 696); (D) laminar and discontinuous clay (hypo-) coatings (arrows) (Sample 696). Microphotographs $(\mathbf{A}, \mathbf{B}, \mathbf{D})$ were taken under plane-polarized light; (C) was taken under crossed nicols. 


\subsection{Black Crusts and Patina}

Black crusts and patinas are common in the studied samples, covering clasts of the conglomeratic host rock or the filling sediments, as well as upholstering walls and delimiting fluid escape structures. These layers are usually very thin, smaller than $1 \mathrm{~mm}$, and when their composition is identifiable in XRD, it can be seen that they are composed of manganese oxides, manganese hydroxides (mainly birnessite), and iron minerals (such goethite and ferrihydrite). From a textural point of view, massive crypto-microcrystalline aggregates are predominant (Figure 11A,B), but laminar and botryoidal textures covering grains (quartz, bone fragments, etc.) or pores are also present (Figure 11C,D). Semiquantitative chemical analyses (EDSs) seem to indicate that iron-rich mineral phases predominate in grain and clast coatings, while manganese precipitates predominate in crusts and impregnations in fine sediments (Table 3).
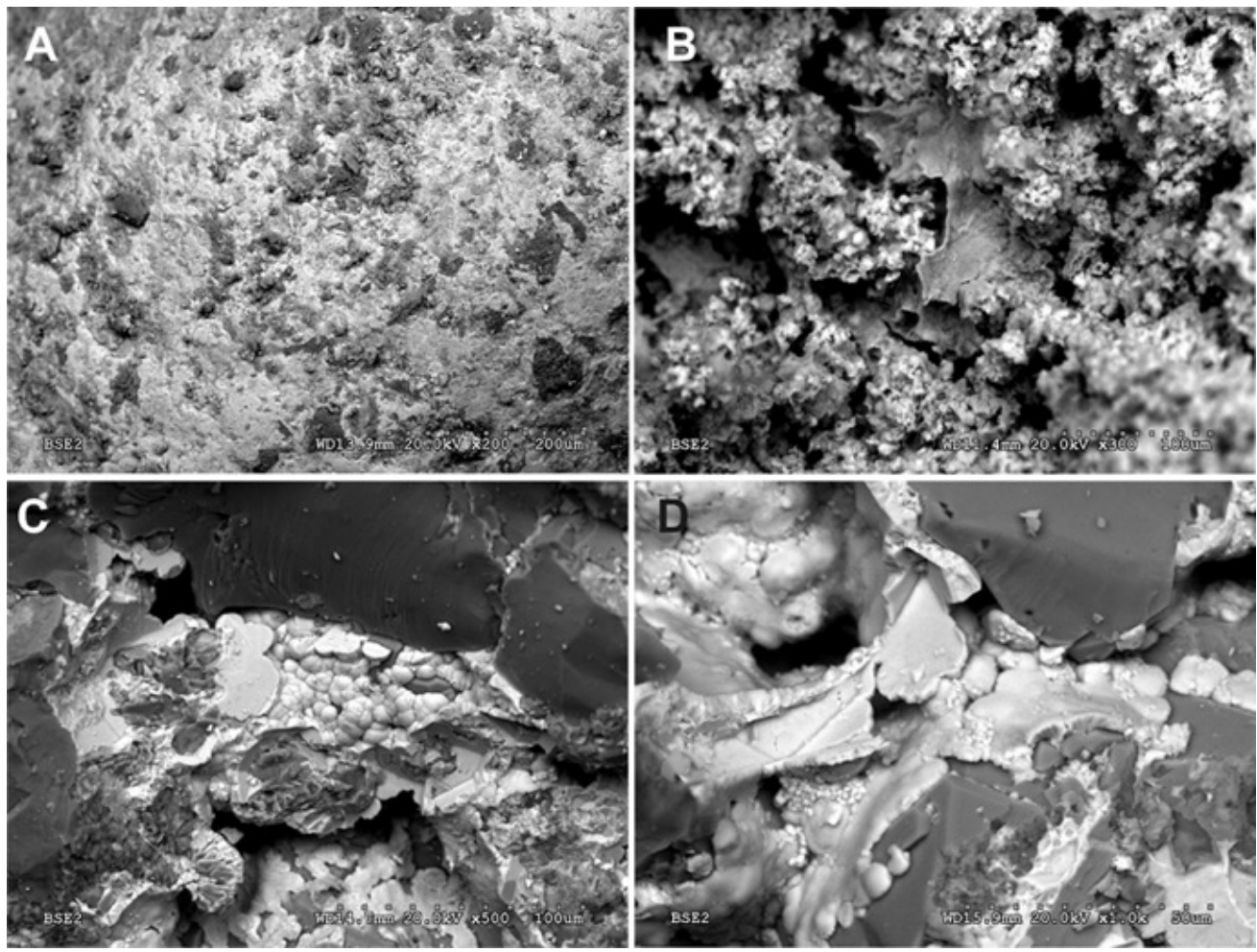

Figure 11. Fe-Mn deposits: (A) iron-rich patina covering a siliciclastic grain (Sample Sid-04); (B) anhedral masses of Fe and Mn oxides (Sample Sid-06); (C,D) ferruginous cements with a botryoidal texture (Sample Sid-05).

Table 3. Chemical composition (EDS) of black impregnations and coatings. (Sid 01, 02, and 06): black impregnations (mottling); (Sid 04 and 05): grain coatings.

\begin{tabular}{cccccc}
\hline & Sid 01 & Sid 02 & Sid 04 & Sid 05 & Sid 06 \\
\hline $\mathrm{O}$ & 49.45 & 50.64 & 48.63 & 47.15 & 53.50 \\
$\mathrm{C}$ & 15.41 & 21.65 & 11.01 & 15.58 & 8.79 \\
$\mathrm{Si}$ & 2.41 & 5.72 & 4.46 & 3.30 & 1.24 \\
$\mathrm{Al}$ & 4.11 & 4.55 & 3.80 & 2.89 & 6.47 \\
$\mathrm{Mg}$ & 0.46 & 0.38 & 0.19 & 0.29 & - \\
$\mathrm{Fe}$ & 3.26 & 3.91 & 28.98 & 18.02 & 10.10 \\
$\mathrm{Mn}$ & 18.56 & 8.51 & 1.05 & 10.28 & 17.10 \\
$\mathrm{Ca}$ & 3.00 & 3.94 & 1.36 & 2.00 & 2.55 \\
$\mathrm{~K}$ & - & 0.47 & 0.38 & 0.34 & 0.04 \\
$\mathrm{P}$ & 0.38 & 0.25 & 0.14 & 0.16 & 0.21 \\
$\mathrm{~F}$ & 3.03 & - & - & - & - \\
\hline
\end{tabular}




\section{Discussion and Conclusions}

Different types of crusts (and coatings) have been observed to be attached to bone fragments in the Ossuary Gallery sedimentary infill at the El Sidrón Cave archaeological site. From a mineralogical point of view, these crusts are mainly composed of calcite (cements) and quartz (detrital), with lower proportions of feldspars (detrital) and iron and manganese oxides (such as patina and concretions), the latter not quantifiable by XRD. These results indicate the existence of different phases and/or mechanisms of carbonate (calcite) crusting, characterized by variations in the detrital aggregate/cement ratio from the internal to external zones of the bony substrate, as well as by granulometric and textural differences. These differences indicate diverse scenarios, from the initial post-mortem accumulation to the final deposit in the Ossuary Gallery, as well as eventual alterations linked to the changes in the hydrodynamic regime of the gallery.

There is no correlation with the depth at which each sample was found (i.e., the deepest one was not the one with a thickest and largest crusty development). Likewise, there is no clear pattern in the spatial distribution of the crusts according to their typology. Only the crusts that are richer in carbonate (sparitic subtype) were found to be located closer to the cemented flowstone layer at the top of Unit III. The detrital-rich crusts are directly attached to the surface of the bones, and the calcitic crusts (both the micritic and sparitic subtypes) are located on top of the bones.

Micritic crusts show diagenetic microfabrics as clotted-to-peloidal micrite-microsparite, NFC, and clay coatings or cutans that point to microbial biological activity in a subaerial environment [24,35]. Clotted peloidal fabrics are common in microbial formations such as travertines, stromatolites, and thrombolites [36]. The observed NFC aggregates rarely completely fill the pores in which they occur, creating a fine interlacing partial infilling. NFC usually forms in the early phase of pedogenesis and precipitates as cement in vadose conditions [37]. NFC can also be found on cave walls in association with speleothems [38]. NFC's origin has been discussed for many years, but several recent studies have supported arguments for its directly or indirectly biogenic origin [38-40], although the micro-organisms responsible for its formation have still not been identified [40]. However, some studies have suggested that NFCs are largely a product of abiogenic vadose precipitation that involved little or no biological influences [41].

On the other hand, the sparitic crusts formed by palisades of calcitic tabular crystals correspond to episodes of net speleothemic precipitation. The relative proximity of these sparitic coatings to the flowstone deposits that culminate in Unit III (Figures 3 and 6) could be related to the percolation of carbonate-rich water through the sediment and the precipitation of calcite coatings at lower levels. However, the orientation and geometry of these coatings in the studied samples (they do not show pendant geometry or parallel to the surface) indicate that their formation was mostly prior to their arrival to the Ossuary Gallery and to the formation of the speleothems that are associated with its sedimentary infill. Detritus within or associated with these precipitates could have originated from a variety of sources, including air-born silts and clays near cave entrances, transportation by cave ventilation, or fine-grained sediments carried through fractures by infiltrating waters or suspended by floodwaters [42].

Calcite crusts with abundant siliciclastic (terrigenous) grains are the most abundant and most in contact with the bones, which are commonly fragmented and disarticulated. In several samples, these crusts are covered by calcite crusts subtypes (massive peloidal micritic and porous micritic with NFC) (Figure 6) whose formation occurred under subaerial conditions close to the surface in a phase prior to the arrival of the bones to the Ossuary Gallery. The silty (orange) crusts are adhered more or less continuously to the surface of some bones, with their grain size (clay and silt) and the texture (angular and well-sorted) being possibly related to an aeolian origin $[29,43,44]$. Likewise, the existence of accumulations of iron oxides-hydroxides associated with these crusts fits well with an environment of subaerial exposure [29,45]. Sandy (beige) crusts, which are the most abundant and often intercalated with the other types of crusts, contain depositional and post-depositional 
hydromorphic features (i.e., layered clay coatings, extensive iron-manganese impregnation, and desiccation cracks) [34].

Finally, the development of $\mathrm{Fe}-\mathrm{Mn}$ oxides precipitates as grain (including bone fragments) coatings and disperse impregnations on groundmass may have resulted from a hydromorphic process, indicating the movement of water through the profiles under the influence of a shallow groundwater table in an oxic cave environment $[46,47]$. Fe and $\mathrm{Mn}$ oxide deposits formed in this way are common in caves and thought to be primarily mediated by microbial activity [48,49]. Likewise, the formation of these oxides, together with the reprecipitation of calcite as void coats and infillings and the presence of clay-cutans, could indicate soil-formation processes [50,51].

Regarding sediments, no micromorphological features (e.g., hydromorphism and bioturbation) that point to the development of in situ pedogenetic processes in any of the units that make up the sedimentary fill of the site have been recognized. Features such as clay coatings and/or silt cappings may have originated from drip-water that percolates through the sediment and redistributes fine-grained detritus around grains or filling pores.

In summary, the analysis of the crusts adhered to the Neanderthal bones at the Ossuary Gallery has indicated that some of the skeletal remains remained in a surface environment (aeolian patina, illuviation-eluviation features, superficial biogenic crusts, etc.) earlier than their deposition inside the cave. These subtle soil-forming processes must have occurred in areas close to the outside of the karstic system such as cave entrances or rockshelters. Given the few traces of alteration that the bones present, their permanence in superficial conditions must have been short [19,32]. This intermediate storage, like the most superficial location (shelter or entrance to a gallery), is situated in a vadose context, and they are both distant and disconnected from the hydrodynamically active zone of the El Sidrón karst system. At present, that entrance is covered by colluvial deposits and soils on which the current forest is developing. During their post-depositional history, the paleontological bone assemblage suffered from surface bleaching, the loss of organic components, progressive cracking and splintering, and carbonate concretion.

Author Contributions: Conceptualisation, J.C.C., S.S.-M., and M.d.1.R.; investigation, J.C.C., S.S.-M., E.D., G.S.-D., M.C.M.-C., P.G.S., S.C., Á.F.-C., J.L., and M.d.1.R.; writing-original draft, J.C.C. and M.d.l.R. All authors have read and agreed to the published version of the manuscript.

Funding: This work has been supported since 1999 through different research contracts between the Government of the Principality of Asturias, the University of Oviedo, the University of Alicante, the National Museum of Natural Sciences (CSIC, Madrid), and the University of Salamanca.

Data Availability Statement: Not applicable.

Acknowledgments: We want to thank the magnificent team of archaeologists for the invaluable help that they have given us over all these years; they patiently and conscientiously made our work infinitely easier. We also thank Jesús Jordá, Guest Editor of this Special Issue, and the reviewers for their constructive suggestions. In memoriam to our dear Javier Fortea (1946-2009), without whom this work would have been far from perfect, and Manolo Hoyos (1944-1999), a master geologist and pioneering geoarchaeologist.

Conflicts of Interest: The authors declare no conflict of interest.

\section{References}

1. Fortea, J.; Rasilla, M.D.L.; Sánchez-Moral, S.; Cañaveras, J.C.; Cuezva, S.; Rosas, A.; Soler, V.; Julià, R.; Torres, T.D.; Ortiz, J.E.; et al. La cueva de El Sidrón (Borines, Piloña, Asturias): Primeros resultados. Estudios Geológicos 2003, 59, 159-179.

2. Rosas, A.; Martinez-Maza, C.; Bastir, M.; García-Tabernero, A.; Lalueza-Fox, C.; Huguet, R.; Ortiz, J.E.; Julia, R.; Soler, V.; de Torres, T.; et al. Paleobiology and comparative morphology of a late Neandertal sample from El Sidron, Asturias, Spain. Proc. Natl. Acad. Sci. USA 2006, 103, 19266-19271. [CrossRef] [PubMed]

3. Fortea, J.; Rasilla, M.D.L.; Martínez, E.; Sánchez-Moral, S.; Cañaveras, J.C.; Cuezva, S.; Rosas, A.; Soler, V.; Julià, R.; Torres, T.D.; et al. La cueva de El Sidrón (Borines, Piloña, Asturias): Campañas arqueológicas de 2000 a 2002. In Excavaciones Arqueológicas en Asturias 1999-2002; Servicio de Publicaciones: Oviedo, Spain, 2007; Volume 5, pp. 191-205. 
4. Fortea, J.; Rasilla, M.D.L.; Santamaría, D.; Martínez, L.; Duarte, E.; Fernández de la Vega, J.; Martínez, E.; Cañaveras, J.C.; Sánchez-Moral, S.; Cuezva, S.; et al. La cueva de El Sidrón (Borines, Piloña, Asturias). In Campañas Arqueológicas de $2003-2006$. Excavaciones Arqueológicas en Asturias 2003 a 2006; Servicio de Publicaciones: Oviedo, Spain, 2007; Volume 6, pp. 367-384.

5. Lalueza-Fox, C.; Rosas, A.; Estalrrich, A.; Gigli, E.; Campos, P.F.; García-Tabernero, A.; García-Vargas, S.; Sánchez-Quinto, F.; Ramírez, O.; Civit, S.; et al. Genetic evidence for patrilocal mating behaviour among Neandertal groups. Proc. Natl. Acad. Sci. USA 2011, 108, 250-253. [CrossRef]

6. Rosas, A.; Estalrrich, A.; García-Vargas, S.; García-Tabernero, A.; Bastir, M.; Huguet, R.; Peña-Melián, A. Los fósiles neandertales de la cueva de El Sidrón. In La Cueva de El Sidrón (Borines, Piloña, Asturias), 1st ed.; Rasilla, M., Rosas, A., Cañaveras, J.C., Lalueza-Fox, C., Eds.; Investigación Interdisciplinar de un Grupo Neandertal; Consejería de Cultura y Turismo, Gobierno del Principado de Asturias, Trabe SLU: Oviedo, Spain, 2011; Volume 1, pp. 81-116.

7. Lalueza-Fox, C.; Rosas, A.; de la Rasilla, M. Palaeogenetic research at the El Sidrón Neandertal site. Ann. Anat. 2012, 194, 133-137. [CrossRef] [PubMed]

8. Rosas, A.; Estalrrich, A.; García-Tabernero, A.; Bastir, M.; García-Vargas, S.; Sánchez-Meseguer, A.; Huguet, R.; Lalueza-Fox, C.; Peña-Melián, A.; Kranioti, E.F.; et al. Les Néandertaliens d’El Sidrón (Asturies, Espagne). Actualisation d'un nouvel échantillon. L'Anthropologie 2012, 116, 57-76. [CrossRef]

9. Rosas, A.; Estalrrich, A.; García-Tabernero, A.; Huguet, R.; Lalueza-Fox, C.; Ríos, L.; Bastir, M.; Fernández-Cascón, B.; PérezCriado, L.; Rodríguez-Pérez, F.; et al. Investigación paleoantropológica de los fósiles neandertales de El Sidrón (Asturias, España). Cuaternario Geomorfología 2015, 29, 77-94. [CrossRef]

10. Santamaría, D.; Fortea, J.; De La Rasilla, M.; Martínez, L.; Martínez, E.; Cañaveras, J.C.; Sánchez-Moral, S.; Rosas, A.; Estalrrich, A.; García-Tabernero, A.; et al. The technological and typological behaviour of a neanderthal group from el sidrón cave (Asturias, Spain). Oxf. J. Archaeol. 2010, 29, 119-148. [CrossRef]

11. Santamaría, D. La Transición del Paleolítico Medio al Superior en Asturias. El abrigo de La Viña (La Manzaneda, Oviedo) y la Cueva de El Sidrón (Borines, Piloña); Servicio de Publicaciones: Oviedo, Spain, 2012. Available online: http://hdl.handle.net/10651/19328 (accessed on 12 May 2021).

12. Rosas, A.; Huguet, R.; Estalrrich, A.; García-Tabernero, A.; García-Vargas, S.; Bastir, M.; Peña-Melían, Á. Fauna de macromamíferos en la Galería del Osario. In La Cueva de El Sidrón (Borines, Piloña, Asturias), 1st ed.; Rasilla, M.D.L., Rosas, A., Cañaveras, J.C., Lalueza-Fox, C., Eds.; Investigación Interdiscipli-nar de un Grupo Neandertal; Consejería de Cultura y Turismo, Gobierno del Principado de Asturias, Trabe SLU: Oviedo, Spain, 2011; Volume 1, pp. 147-148.

13. De Torres, T.; Ortiz, J.E.; Grun, R.; Eggins, S.; Valladas, H.; Mercier, N.; Tisnérat-Laborde, N.; Juliá, R.; Soler, V.; Martinez, E.; et al. Dating of the hominid (Homo Neanderthalensis) remains accumulation from El Sidrón Cave (Piloña, Asturias, North Spain): An example of a multi-methodological approach to the dating of upper pleistocene sites. Archaeometry 2009, 52, 680-705. [CrossRef]

14. Wood, R.E.; Higham, T.F.G.; Torres, T.D.; Tisnérat-Laborde, N.; Valladas, H.; Ortiz, J.E.; Lalueza, C.; Sánchez-Moral, S.; Cañaveras, J.C.; Rosas, A.; et al. A new date for the Neanderthals from El Sidrón Cave (Asturias, Northern Spain). Archaeometry 2013, 55, 148-158. [CrossRef]

15. Alonso, J. Descripción física del complejo cárstico y sus conexiones exteriores. In La Cueva de El Sidrón (Borines, Piloña, Asturias), 1st ed.; Rasilla, M., Rosas, A., Cañaveras, J.C., Lalueza-Fox, C., Eds.; Investigación Interdisciplinar de un Grupo Neandertal; Consejería de Cultura y Turismo, Gobierno del Principado de Asturias, Trabe SLU: Oviedo, Spain, 2011; Volume 1, pp. 21-26.

16. Cañaveras, J.C.; Sánchez-Moral, S.; Lario, J.; Cuezva, S.; Fernández, A.; Muñoz, M.C. El modelo de relleno, o cómo llegaron los restos a la Galería del Osario. In La Cueva de El Sidrón (Borines, Piloña, Asturias), 1st ed.; Rasilla, M., Rosas, A., Cañaveras, J.C., Lalueza-Fox, C., Eds.; Investigación Interdisciplinar de un Grupo Neandertal; Consejería de Cultura y Turismo, Gobierno del Principado de Asturias, Trabe SLU: Oviedo, Spain, 2011; Volume 1, pp. 43-63.

17. Martínez García, E. Evolución geológica de la zona de El Sidrón y sus áreas limítrofes. In La Cueva de El Sidrón (Borines, Piloña, Asturias), 1st ed.; Rasilla, M., Rosas, A., Cañaveras, J.C., Lalueza-Fox, C., Eds.; Investigación Interdisciplinar de un Grupo Neandertal; Consejería de Cultura y Turismo, Gobierno del Principado de Asturias, Trabe SLU: Oviedo, Spain, 2011; Volume 1, pp. 29-33.

18. Silva, P.G.; Santos, G.; Carrasco, P.; Huerta, P.; Ayarza, P.; Álvarez Lobato, F.; Fernández Macarro, B.; Standing, M. La geomorfología, topografía y prospección geofísica del complejo de El Sidrón. La búsqueda del lugar de procedencia de los restos fósiles. In La Cueva de El Sidrón (Borines, Piloña, Asturias), 1st ed.; Rasilla, M., Rosas, A., Cañaveras, J.C., Lalueza-Fox, C., Eds.; Investigación Interdisciplinar de un Grupo Neandertal; Consejería de Cultura y Turismo, Gobierno del Principado de Asturias, Trabe SLU: Oviedo, Spain, 2011; Volume 1, pp. 65-79.

19. Cañaveras, J.C.; Sánchez-Moral, S.; Cuezva, S.; Fernández-Cortés, A.; Muñoz, M.C.; Silva, P.G.; Santos, G.; Duarte, E.; Santamaría, D.; Rasilla, M.D.L. Estudio Geoarqueológico de la Cueva de El Sidrón (Asturias); Boletín del Instituto Geológico y Minero: Madrid, Spain, 2018; Volume 129, pp. 107-128.

20. Collcutt, S.N. The analysis of quaternary cave sediments. World Archaeol. 1979, 10, 290-301. [CrossRef]

21. Farrand, W.R. Sediments and stratigraphy in rock shelters and caves: A personal perspective on principles and pragmatic. Geoarchaeology 2001, 16, 537-557. [CrossRef]

22. Goldberg, P.; Macphail, R.I. Practical and Theoretical Geoarchaeology; Wiley-Blackwell, TJ International, Padstow: Cornwall, UK, 2005. 
23. Goldberg, P.; Sherwood, S.D. Deciphering human prehistory through the geoarchaeological study of cave sediments. Evol. Anthropol. 2006, 15, 20-36. [CrossRef]

24. Polo, A.; Fernández-Eraso, J. Same anthropogenic activity, different taphonomic processes: A comparison of deposits from Los Husos I \& II (Upper Ebro Basin, Spain). Quatern. Int. 2010, 214, 82-97.

25. White, E.M.; Hannus, L.A. Chemical weathering of bone in archaeological soils. Am. Antiq. 1983, 48, 316-322. [CrossRef]

26. Stephan, E. Patterns of chemical change in fossil bones and various states of bone preservation associated with soil conditions. Anthropozoologica 1997, 25, 173-180.

27. Nielsen-Marsh, C.M.; Hedges, R.E. Patterns of diagenesis in bone I: The effects of site environments. J. Archaeol. Sci. 2000, 27, 1139-1150. [CrossRef]

28. Hedges, R.E.M. Bone diagenesis: An overview of processes. Archaeometry 2002, 44, 319-328. [CrossRef]

29. Reiche, I.; Favre-Quattropani, L.; Vignaud, C.; Bocherens, H.; Charlet, L.; Menu, M. A multi-analytical study of bone diagenesis: The neolithic site of bercy (Paris, France). Meas. Sci. Technol. 2003, 14, 1608-1619. [CrossRef]

30. Karkanas, P.; Goldberg, P. Site formation processes at pinnacle point cave 13B (Mossel Bay, Western Cape Province, South Africa): Resolving stratigraphic and depositional complexities with micromorphology. J. Hum. Evol. 2010, 59, 256-273. [CrossRef] [PubMed]

31. Sánchez-Moral, S.; Cañaveras, J.C.; Lario, J.; Cuezva, S.; Silva, P.G.; Rasilla, M.D.L.; Fortea, J. Caracterización del relleno sedimentario de la Galería del Osario (cueva de El Sidrón, Asturias, España). In XII Reunión Nacional de Cuaternario; Lario, J., Silva, P.G., Eds.; AEQUA: Ávila, Spain, 2007; pp. 123-124.

32. Rosas, A.; Estalrrich, A.; García-Vargas, S.; García-Tabernero, A.; Huguet, R.; Lalueza-Fox, C.; Rasilla, M.D.L.; Fortea, J. Identification of neandertal individuals in fragmentary fossil assemblages by means of teeth associations. The case of the El Sidrón (Asturias, Spain). C. R. Palevol 2013, 12, 279-291. [CrossRef]

33. Martín-Ramos, J.; Diazhernandez, J.L.; Cambeses, A.; Scarrow, J.H.; Lpez-Galindo, A. Pathways for quantitative analysis by X-ray diffraction. In An Introduction to the Study of Mineralogy; Aydinalp, C., Ed.; IntechOpen: Rijeka, Croatia, $2012 ;$ pp. 73-92.

34. Rosas, A.; Fortea, J.; Rasilla, M.D.L.; Fernández, P.; Hidalgo, A.; Lacasa, E.; Martínez-Maza, C.; García Tabernero, A.; Bastir, M. Restos neandertales de la Cueva de El Sidrón (Borines, Piloña, Asturias): Una restauración al servicio de la investigación paleontológica. PH Boletín Instituto Andaluz Patrimonio Histórico 2005, 53, 70-73.

35. Mallol, C.; Mentzer, S.M.; Wrinn, P.J. A micromorphological and mineralogical study of site formation processes at the late Pleistocene site of Obi-Rakhmat, Uzbekistan. Geoarchaeology 2009, 24, 548-575. [CrossRef]

36. Riding, R. Microbial carbonates: The geological record of calcified bacterial-algal mats and biofirms. Sedimentology 2000, 47, 179-214. [CrossRef]

37. Verrecchia, E.P.; Verrecchia, K.E. Needle fiber calcite: A critical review and a proposed classification. J. Sediment. Res. 1994, 64, 650-664.

38. Cañaveras, J.C.; Cuezva, S.; Sanchez-Moral, S.; Lario, J.; Laiz, L.; Gonzalez, J.M.; Saiz-Jimenez, C. On the origin of fiber calcite crystals in moonmilk deposits. Naturwissenschaften 2005, 93, 27-32. [CrossRef] [PubMed]

39. Sanchez-Moral, S.; Portillo, M.C.; Janices, I.; Cuezva, S.; Fernandez-Cortes, A.; Cañaveras, J.C.; Gonzalez, J.M. The role of microorganisms in the formation of calcitic moonmilk deposits and speleothems in Altamira Cave. Geomorphology 2012, 139-140, 285-292. [CrossRef]

40. Cailleau, G.; Verrecchia, E.P.; Braissant, O.; Emmanuel, L. The biogenic origin of needle fibre calcite. Sedimentology 2009, 56, 1858-1875. [CrossRef]

41. Jones, B.; Peng, X. Abiogenic growth of needle-fiber calcite in spring towers at Shiqiang, Yunnan Province, China. J. Sediment. Res. 2014, 84, 1021-1040. [CrossRef]

42. Denniston, R.F.; Luetscher, M. Speleothems as high-resolution paleoflood archives. Quat. Sci. Rev. 2017, 170, 1-13. [CrossRef]

43. Goldberg, P. Micromorphology and site formation at Die Kelders Cave I, South Africa. J. Hum. Evol. 2000, 38, 43-90. [CrossRef]

44. Macphail, R.I.; Goldberg, P. Geoarchaeological investigation of sediments from Gorham's and Vanguard caves, Gibraltar: Microstratigraphical (soil micromorphological and chemical) signatures. In Neanderthals on the Edge; Stringer, C.B., Barton, R.N., Finlayson, J.C., Eds.; Oxbow Books: Oxford, UK, 2000; pp. 183-200.

45. Hill, C.A. Origin of Black Deposits in Caves; National Speleological Society: Huntsville, AL, USA, 1982; Volume 44, pp. 15-19.

46. Hill, C.A.; Forti, P. Cave Minerals of the World, 2nd ed.; National Speleological Society: Huntsville, AL, USA, 1997.

47. López-González, F.; Grandal-D’Anglade, A.; Vidal-Romaní, J.R. Deciphering bone depositional sequences in caves through the study of manganese coatings. J. Archaeol. Sci. 2006, 33, 707-717. [CrossRef]

48. Baskar, S.; Baskar, R.; Lee, N.; Kaushik, A.; Theophilus, P.K. Precipitation of iron in microbial mats of the spring waters of Borra Caves, Vishakapatnam, India: Some geomicro-biological aspects. Environ. Geol. 2008, 56, 237-243. [CrossRef]

49. Frierdich, A.J.; Catalano, J.G. Distribution and speciation of trace elements in iron and manganese oxide cave deposits. Geochim. Cosmochim. Acta 2012, 91, 240-253. [CrossRef]

50. Karkanas, P.; Goldberg, P. Micromorphology of cave sediments. In Treatise on Geomorphology, Karst Geomorphology; Shroder, J., Frumkin, S., Eds.; Academic Press: San Diego, CA, USA, 2013; Volume 6, pp. 286-297.

51. Stoops, G.; Melo, V.D.; Mees, F. Micromorphological features and their relation to processes and classification: General guidelines and overview. In Interpretation of Micromorphological Features of Soils and Regoliths, 2nd ed.; Stoops, G., Melo, V.D., Mees, F., Eds.; Elsevier: Amsterdam, The Netherlands, 2018; pp. 895-917. 